\title{
THE GEOCHEMISTRY OF ICE IN THE SOUTHEASTERN ALPS, SLOVENIA
}

Anne Carey, Devin Smith, Susan Welch, Matija Zorn, Jure Tičar,

Matej Lipar, Blaž Komac, Berry Lyons

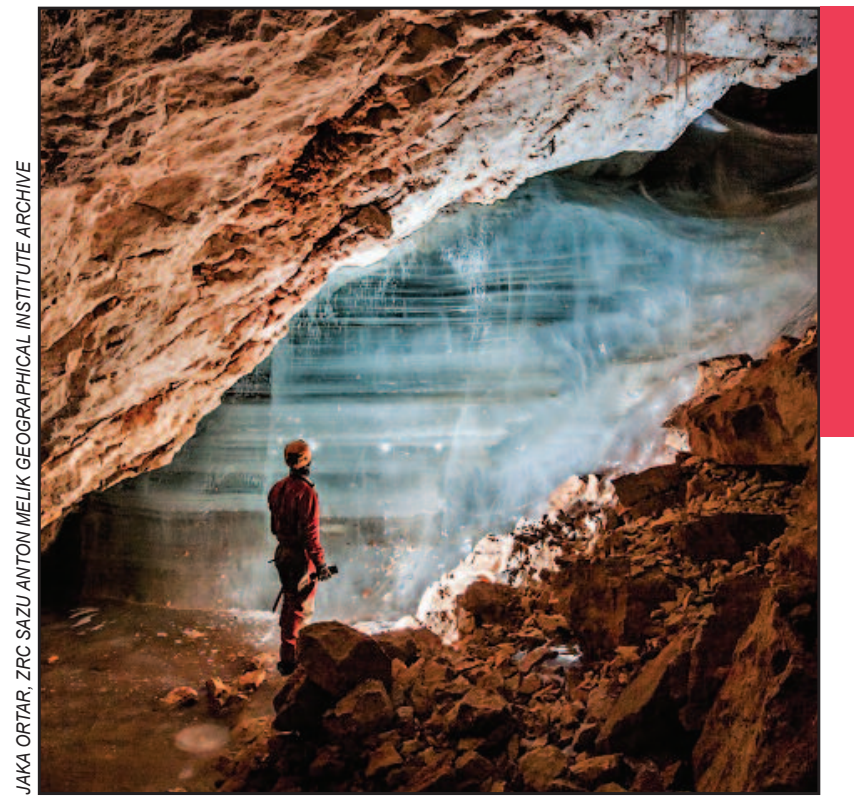

Cave ice in the Ivačičeva Cave in the Julian Alps (southeastern Alps, Slovenia). 
DOI: https://doi.org/10.3986/AGS.7420

UDC: 911.2:551.324(234.323.6)

$551.324: 550.4(234.323 .6)$

COBISS: 1.01

Anne Carey ${ }^{1}$, Devin Smith², Susan Welch', Matija Zorn ${ }^{3}$, Jure Tičar ${ }^{3}$, Matej Lipar ${ }^{3}$, Blaž Komac ${ }^{3}$, Berry Lyons ${ }^{1}$

\section{The geochemistry of ice in the southeastern Alps, Slovenia}

ABSTRACT: The Triglav Glacier in the Julian Alps and the Skuta Glacier in the Kamnik-Savinja Alps are among the south-easternmost glaciers in the Alps. Historical data show that ice masses are undergoing mass loss as the overall climate warms. Glacier ice and cave ice contain a wealth of paleoclimatic information, and rapid sampling is needed if any such information is to be saved before the ice is completely melted. We present the first comprehensive geochemical and water isotope data from glacier ice, meltwater, spring water, and cave ice in the Mount Triglav area and glacier ice from the Skuta Glacier. The samples primarily reflect the initial precipitation signal that has been greatly modified by the input of local $\mathrm{CaCO}_{3}$-rich dust with lesser amounts of marine aerosol and vegetation debris.

KEY WORDS: glaciochemistry, glaciokarst, ice caves, cave ice, water isotope, Triglav Glacier, Skuta Glacier, Alps

\section{Geokemija ledu v jugovzhodnih Alpah, Slovenija}

POVZETEK: Triglavski ledenik v Julijskih Alpah in Ledenik pod Skuto v Kamniško-Savinjskih Alpah sta med najbolj jugovzhodnimi ledeniki v Alpah. Njuno dolgoletno opazovanje kaže, da se ledenika zaradi segrevanja ozračja krčita. Ker ledeniški in jamski led hranita številne podatke o preteklem podnebju, je njuno vzorčenje nujno, dokler so podatki (led) še na razpolago. V članku predstavljamo prve obsežnejše podatke o geokemiji in vodnih izotopih iz ledeniškega ledu, talilne vode, izvirske vode in jamskega ledu na območju Triglava ter ledeniškega ledu iz Ledenika pod Skuto. Vzorci v prvi vrsti odražajo začetni signal padavin, ki je bil močno spremenjen $\mathrm{z}$ vnosom aerosola, obogatenega s karbonatom ter $\mathrm{v}$ manjši meri $\mathrm{z}$ delci morskega in rastlinskega izvora.

KLJUČNE BESEDE: geokemija, glaciokras, ledene jame, jamski led, vodni izotopi, Triglavski ledenik, Ledenik pod Skuto, Alpe

The paper was submitted for publication on January $17^{\text {th }}, 2019$.

Uredništvo je prejelo prispevek 17. januarja 2019.

\footnotetext{
${ }^{1}$ The Ohio State University, School of Earth Sciences, Byrd Polar and Climate Research Center, Columbus, Ohio, USA carey.145@osu.edu (https://orcid.org/0000-0002-0272-5254), welch.318@osu.edu, lyons.142@osu.edu (https://orcid.org/0000-0002-3143-7251)

2 The Ohio State University, School of Earth Sciences, Columbus, Ohio, USA smith.11880@osu.edu (https://orcid.org/0000-0001-6945-7306)

${ }^{3}$ Research Centre of the Slovenian Academy of Sciences and Arts, Anton Melik Geographical Institute, Ljubljana, Slovenia matija.zorn@zrc-sazu.si (https://orcid.org/0000-0002-5788-018X), jure.ticar@zrc-sazu.si (https://orcid.org/0000-0003-3567-8084), matej.lipar@zrc-sazu.si (https://orcid.org/0000-0003-4414-0147), blaz.komac@zrc-sazu.si (https://orcid.org/0000-0003-4205-5790)
} 


\section{Introduction}

The Triglav Glacier in the Julian Alps (NW Slovenia) at app. 2450-2550 m and the Skuta Glacier in the Kamnik-Savinja Alps (N Slovenia) at app. 2000-2200 m are the only glacier remains in Slovenia (Gabrovec et al. 2013; 2014; Triglav Čekada et al. 2020; Triglav Čekada and Zorn 2020; Figure 1) and among the southeasternmost glaciers in the Alps (Grunewald and Scheithauer 2010). Due to their small size and the relief-dependent lack of movement, they are defined as glacierets (Kumar 2011). As such, from the environmental perspective they represent important mountain geomorphosites (Reynard and Coratza 2016).

The beginning of the research of the Slovenian Alps dates back to the $17^{\text {th }}$ and $18^{\text {th }}$ century (Mikša and Zorn 2016), and the size of the Triglav Glacier has been estimated as far back in time as 1897 (Triglav Čekada, Zorn and Colucci 2014; Del Gobbo et al. 2016). Excellent historical data on the Triglav and Skuta glaciers are available due to continuous detailed measurements of both glaciers by the ZRC SAZU Anton Melik Geographical Institute since 1946 and 1948, respectively (Pavšek 2004; 2007; Gabrovec et al. 2013; 2014). Between the years 2000 and 2013 the ice volume of the Triglav Glacier has decreased from $35,000 \mathrm{~m}^{3}$ to app. 7,400 $\mathrm{m}^{3}$ (Del Gobbo et al. 2016) and has probably reached the smallest size since the Last Glacial Maximum (Lipar et al. 2021). The Skuta Glacier has also experienced mass loss during the past six to seven decades (Pavšek 2007; Triglav Čekada et al. 2020).

Glacier ice and cave ice represent a wealth of paleoclimatic information (Yao et al. 2011), but work in Slovenia (Mihevc 2018) and in other parts of the Julian Alps (Colucci et al. 2016) indicates that, like the Triglav and Skuta glaciers, these ice masses continue to undergo mass loss as the overall climate warms. Rapid sampling of these deposits is needed if any such information is to be preserved. In this paper we present the first comprehensive geochemical and water isotope data, collected in 2017 and 2018, from both ice and meltwater from Triglav and Skuta glaciers' areas. These data also include measurements of cave ice from the Ivačičeva Cave (IC; Figures 2 and 4) and the Triglav Shaft (TS; Figures 3 and 4) located very close to the Triglav Glacier, and water from the spring of the Triglavska Bistrica Creek (TBC) in the Vrata Valley below the Triglav Glacier (TG) at $1175 \mathrm{~m}$ (Figure 1). The purpose of this work was to describe the chemistry of the ice and its meltwater and to provide new information on the isotopic composition at this elevation in the Julian Alps and the Kamnik-Savinja Alps. We also continue to evaluate the potential for use of cave ice in paleoclimatological studies (Carey et al. 2019). In addition, we discuss the hydrological connectivity among precipitation (i.e., glacier ice), meltwater, cave ice and karst spring water in glaciokarst landscape (Zorn, Hrvatin and Perko 2020).

\section{Study area and methods}

\subsection{Study area}

The Mount Triglav (2864 m; Julian Alps) regional landscape has been termed glaciokarst (Kunaver 1983; Žebre and Stepišnik 2015) with the flatter depressions in the landscape providing locations for the collection and accumulation of winter snow (Del Gobbo et al. 2016). The ice samples from the Triglav Glacier (TG) area come from the glacier, the Triglav Shaft (TS; Triglavsko brezno) and Ivačičeva Cave (IC; Ivačičeva jama). The Triglav Shaft is a vertical ice cave $274 \mathrm{~m}$ deep. Entrance to the cave occurs at $2377 \mathrm{~m}$ and was covered by the glacier until the early $20^{\text {th }}$ century. The Ivačičeva Cave is situated next to the Kredarica mountain hut at $2457 \mathrm{~m}$ (Tičar et al. 2018). The spring water sample is from spring of the Triglavska Bistrica Creek (TBC) in the Vrata Valley which is app. $1200 \mathrm{~m}$ directly below the Triglav Glacier and Triglav Shaft (Figure 1).

The Julian Alps bedrock is dominated by Triassic-Jurassic shallow water carbonate rocks (Šmuc and Rožič 2009). There is a weather observatory at $2514 \mathrm{~m}$ that is less than $0.5 \mathrm{~km}$ from the glacier. The mean annual temperature during $1981-2010$ was $-1.0 \pm 0.6^{\circ} \mathrm{C}$ and the mean annual precipitation was $2070 \mathrm{~mm}$ (water equivalent), with mean winter snow accumulation of $5.14 \mathrm{~m}$ (Del Gobbo et al. 2016). The wind 
Carey et al., The geochemistry of ice in the southeastern Alps, Slovenia

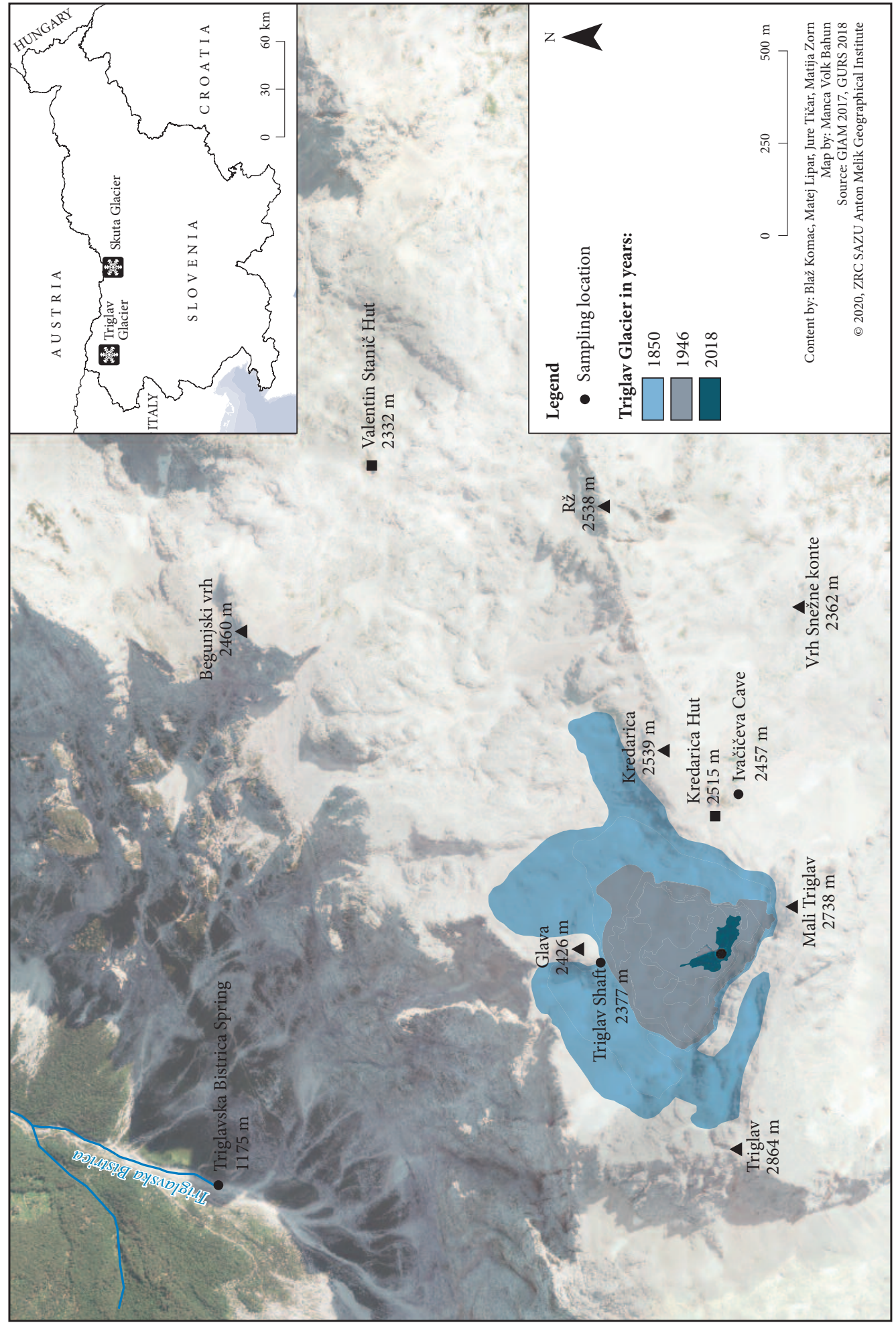




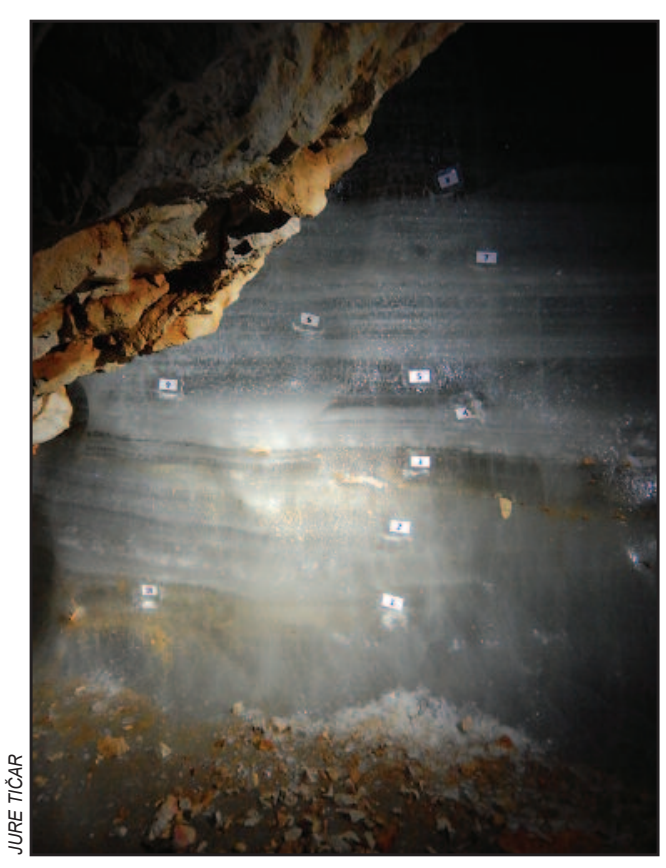

Figure 2: Ice sampling in the Ivačičeva Cave.

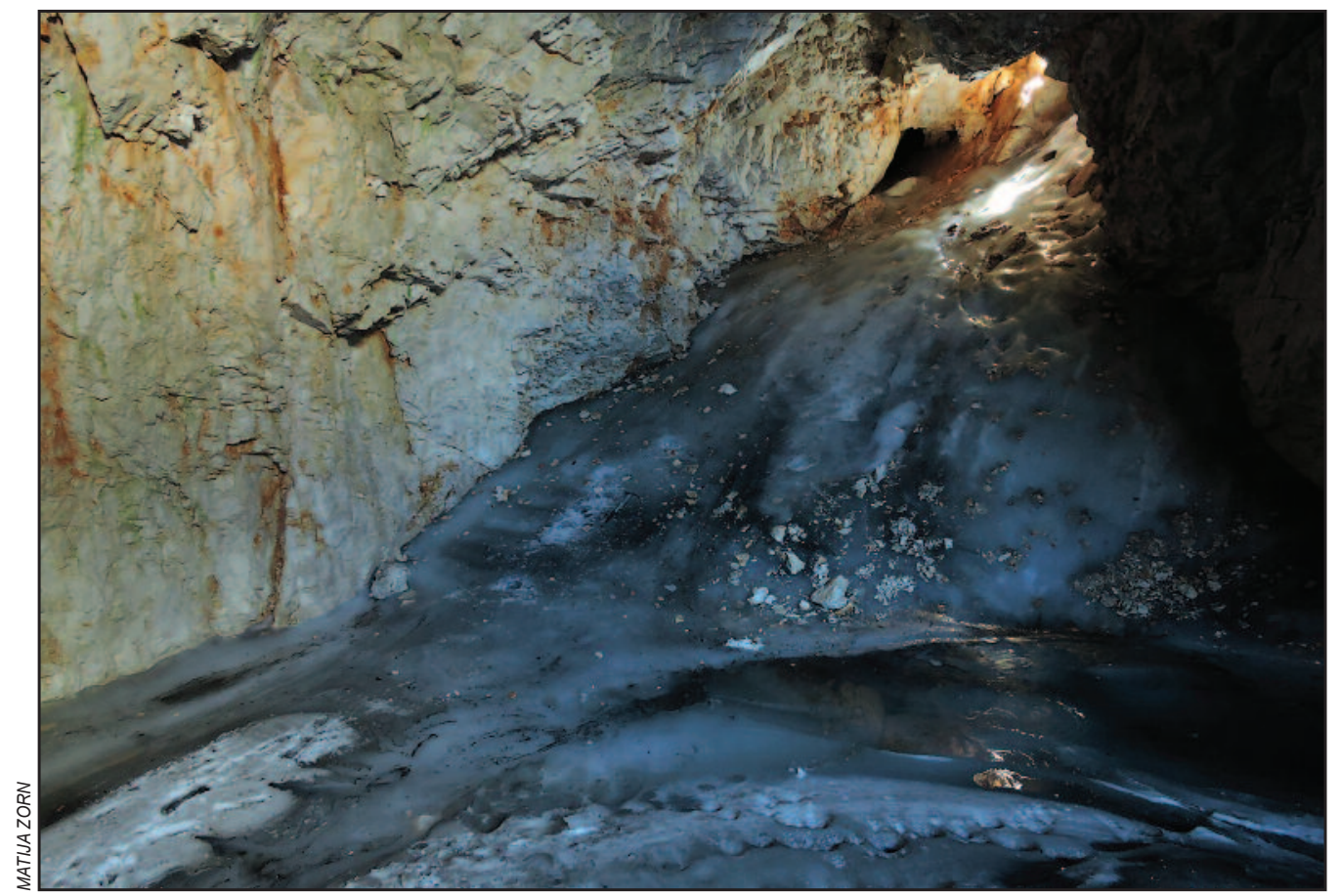

Figure 3: Entrance chamber of the Triglav Shaft where ice samples were taken.

Figure 4: Sketch of the entrance part of the Triglav Shaft and the Ivačičeva Cave with the location of sampling (black dot). $>$ p. 146 
Carey et al., The geochemistry of ice in the southeastern Alps, Slovenia

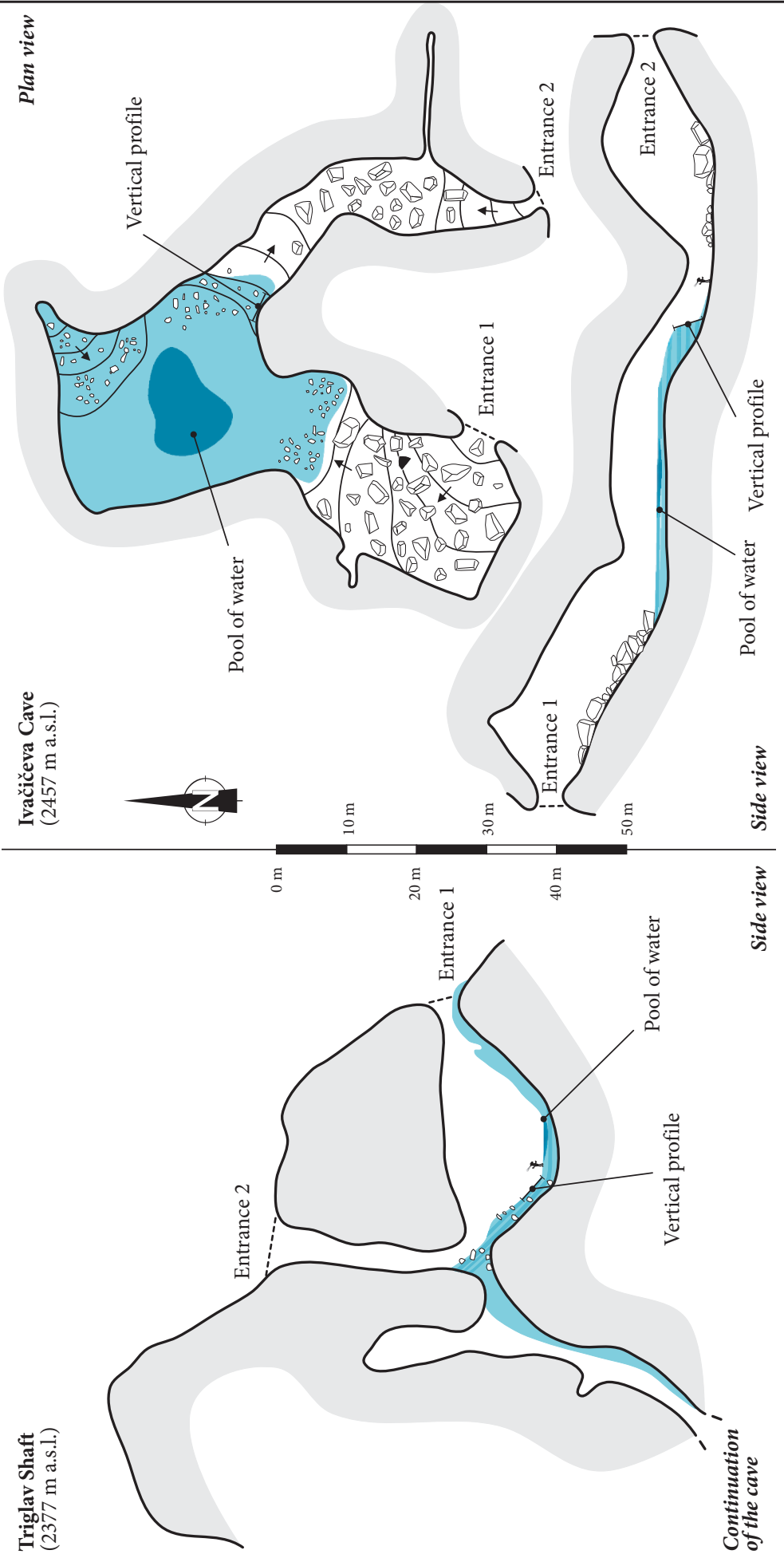


direction is influenced by the top of Mt. Triglav just west from the station, thus the prevailing winds come from northwest or southeast with speeds up to $190 \mathrm{~km} / \mathrm{h}$ (Nadbath 2014).

Ice was also sampled from the Skuta Glacier (SG; Figure 1). The Skuta Glacier (Kamnik-Savinja Alps) is located in a cirque oriented toward the northwest, which preserves it from the Sun for most of the year and also influences the wind direction. The glacier lies at an average elevation of app. $2070 \mathrm{~m}$. The broader Mt. Skuta (2532 m) area is dominated by Triassic carbonate rocks (Mioč 1983), so the setting of the glacier is also in a karstic environment. Both glaciers are fed with snow also through avalanches.

\subsection{Methods}

Ice samples were collected using a clean ice axe, placed into plastic bags and allowed to melt. Samples for ion analysis were filtered in the laboratory through $0.45 \mu \mathrm{m}$ pore size Millipore filters using clean plastic syringes into precleaned low density polyethylene bottles, as discussed in Carey et al. (2019). Samples for water isotope analyses were not filtered but immediately upon complete melting of the ice, the resultant water was decanted into scintillation vials, minimizing any headspace. Water samples were collected directly into precleaned polyethylene bottles and filtered (except the isotope samples) using the same technique as the melted ice.

The samples were kept in the dark in a refrigerator until shipped to the laboratory at The Ohio State University. Major ions were analyzed by ICP-OES (Inductively Coupled Plasma Optical Emission Spectrometry) and ion chromatographic techniques (Welch et al. 2010). Nutrients $\left(\mathrm{NO}_{2}^{-}+\mathrm{NO}_{3}{ }^{-}, \mathrm{NH}_{4}{ }^{+}\right.$, $\mathrm{PO}_{4}{ }^{3-}$ and $\mathrm{H}_{4} \mathrm{SiO}_{4}$ ) were determined with a Skalar $\mathrm{SAN++}$ nutrient analyzer using methods supplied by the manufacturer. The $\delta^{18} \mathrm{O}$ and $\delta \mathrm{D}$ of water were analyzed using a Picarro liquid water isotope analyzer. Samples were compared to VSMOW $\left(\delta^{18} \mathrm{O}=0 \%\right.$; $\delta^{2} \mathrm{H}=0 \%$ ) and to internal laboratory standards as a means of correcting raw data. Some of the ice collection bags were filled with our cleanest deionized water and analyzed as samples to provide any evidence of contamination from the bags and these were used as blanks. Chloride, sulfate, sodium and potassium in these blanks were below our levels of detection while magnesium and calcium concentrations had mean values of $0.9 \mu \mathrm{M}$ and $3.5 \mu \mathrm{M}$, respectively. Details on accuracy and precision can be found in Welch et al. (2010) and Carey et al. (2019). Bicarbonate concentrations were determined by the difference in charge balance as $\mathrm{HCO}_{3}{ }^{-}=\Sigma$ cations $-\sum$ anions as discussed in Welch et al. (2010).

\section{Results}

The major ion and nutrient data are presented in Table 1 . Several general statements can be made about the data. They include, in general, $\mathrm{Ca}>>\mathrm{Mg}=\mathrm{Na}>\mathrm{K} ; \mathrm{HCO}_{3}>\mathrm{SO}_{4}>\mathrm{Cl}$; $\Sigma \mathrm{DIN}$ (sum of $\mathrm{NO}_{2}{ }^{-}+\mathrm{NO}_{3}{ }^{-}+$ $\mathrm{NH}_{4}^{+}$) $>>\mathrm{PO}_{4}^{3-}$; except for the Triglavska Bistrica Spring (TBC) in the Vrata Valley, $\mathrm{H}_{4} \mathrm{SiO}_{4}$ concentrations are very low. The $\delta^{18} \mathrm{O}$ and $\delta \mathrm{D}$ range between $-8.1 \%$ and $-12.7 \%$ and between $-56.3 \%$ and $-96.4 \%$, respectively (Table 2). We have plotted our isotopic analyses of the ice with a regional meteoric water line which we developed from published data (Figure 5). The isotope values all fall on or very close to the regional meteoric water line. The very high $\mathrm{Ca}$ and $\mathrm{HCO}_{3}$ values strongly indicate that all the ice and snow are greatly influenced by local $\mathrm{CaCO}_{3}$-rich dust.

\section{Discussion}

\subsection{Geochemical data}

The mean values for both the glacier and cave ice in the Triglav Glacier area (Table 2) are compared to a high elevation snow pit and ice core data from Mt. Ortles, Italy (Gabrielli et al. 2010) and the closest ice core to the Triglav Glacier as the Mt. Ortles core is the only core taken from the Eastern Alps, near the border of Italy, Switzerland and Austria. These samples from Italy were collected at an elevation of $3860 \mathrm{~m}$ and is the nearest high-elevation ice data adjacent to ice-free areas. These ice data represent a regional picture of high elevation precipitation chemistry in this area of the Alps and it is the nearest ice core analyzed 


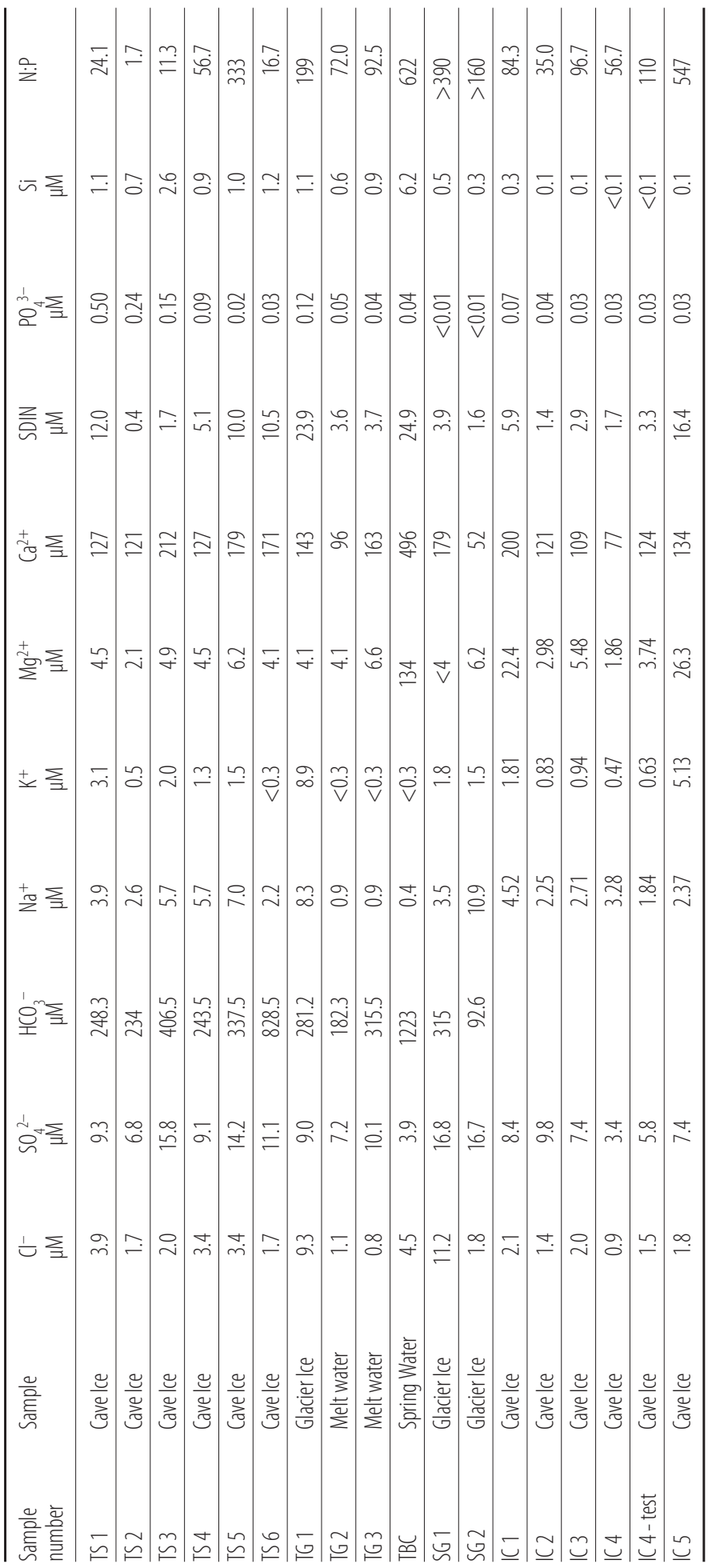


Acta geographica Slovenica, 60-2, 2020

Table 2: Stable isotope analyses of ice and water samples compared to VSMOW $\left(\delta^{18} 0=0 \% ; \delta^{2} H=0 \% 0\right)$.

\begin{tabular}{|c|c|c|c|c|c|}
\hline \multirow{2}{*}{$\begin{array}{l}\text { Sample } \\
\text { number }\end{array}$} & \multirow[t]{2}{*}{ Sample } & \multicolumn{2}{|c|}{ Values } & \multicolumn{2}{|c|}{ Accuracy } \\
\hline & & $\delta^{18} 0, \%$ & $\delta D, \% 0$ & $\delta^{18} 0, \% 0$ & $\delta D, \%$ \\
\hline TS 1 & Cave Ice & -12.10 & -87.44 & 0.08 & 1.51 \\
\hline TS2 & Cave Ice & -11.38 & -77.05 & 0.08 & 1.51 \\
\hline TS 3 & Cave Ice & -9.64 & -65.40 & 0.08 & 1.51 \\
\hline TS 4 & Cave lce & -10.53 & -72.54 & 0.08 & 1.51 \\
\hline TS5 & Cave Ice & -11.96 & -82.15 & 0.08 & 1.51 \\
\hline TS 6 & Cave Ice & -10.67 & -79.79 & 0.08 & 1.51 \\
\hline TG 1 & Glacier Ice & -10.08 & -68.63 & 0.08 & 1.51 \\
\hline TG 2 & Melt water & -8.06 & -52.72 & 0.08 & 1.51 \\
\hline TG3 & Melt water & -8.15 & -52.37 & 0.08 & 1.51 \\
\hline $\mathrm{TBC}$ & Spring Water & -9.84 & -64.94 & 0.08 & 1.51 \\
\hline SG 1 & Glacier Ice & -8.69 & -58.06 & 0.08 & 1.22 \\
\hline$S G 2$ & Glacier Ice & -8.90 & -58.72 & 0.08 & 1.22 \\
\hline IC 1 & Cave Ice & -8.82 & -57.46 & 0.05 & 0.59 \\
\hline IC2 & Cave Ice & -8.63 & -57.04 & 0.05 & 0.59 \\
\hline $\mathrm{IC} 3$ & Cave Ice & -8.40 & -54.16 & 0.05 & 0.59 \\
\hline IC 4 & Cave lce & -8.54 & -56.14 & 0.05 & 0.59 \\
\hline IC 4 - test & Cave lce & -9.01 & -59.90 & 0.05 & 0.59 \\
\hline IC5 & Cave Ice & -8.12 & -53.75 & 0.05 & 0.59 \\
\hline
\end{tabular}

for some of the same analyzed in our samples. We assume that the precipitation regime in the Triglav region is generally similar to that in the Mt. Ortles area and it is then modified, either by the input of chemicals as the precipitation falls or after it is deposited on the glacier surface. Enrichment factors (Triglav ice/Mt. Ortles snow) can then be computed for elements under investigation (Table 1). These enrichment factors range from as little as 1.1 for $\mathrm{Mg}$ and as high as 19.1 for $\mathrm{Ca}$ (Table 3). Calcium in the Mt. Ortles snow has been shown to be a proxy for »dust « (Gabrielli et al. 2010). Because the surrounding bedrock in the Triglav area is carbonate, we assume that these very large enrichments of $\mathrm{Ca}$ in the Triglav ice and in the meltwater are both due to the local input of $\mathrm{CaCO}_{3}$-rich dust. The dust either dissolves as the ice melts or is solubilized when acid is added to the cation samples prior to ICP-OES analysis, or both. The lesser enrichments in $\mathrm{Cl}, \mathrm{SO}_{4}, \mathrm{Na}$, and $\mathrm{K}$ are probably also related to increased particle input from marine aerosol, pollution, and/or organic matter debris deposited as primary precipitation or blown onto the glacier surface as aeolian deposition through time. The very low $\mathrm{H}_{4} \mathrm{SiO}_{4}$ values suggest, however, that the deposited dust either is extremely low in silicate minerals or that these minerals are filtered out of the sample during processing. We have observed debris on the filter paper after filtration so the latter is more likely. This phenomenon of local dust deposition onto glacier surfaces has been observed on many glaciers all over the world, including on glaciers in the ice-free regions of Antarctica where local soils can be suspended and re-deposited by winds (Lyons et al. 2002; 2020). In addition, local dust deposition and erosion commonly occur in Slovenia, even in lower-lying regions (e.g., Zorn 2009; Miler 2014; Miler and Gosar 2015; Zupančič, Horvat and Skobe 2015).

The cave ice has a geochemistry similar to the meltwater, which may suggest that the cave ice is formed from the refreezing of summer glacier melt (Table 1).

DIN concentrations have mean value of $6.3 \mu \mathrm{M}$ and median of only $3.3 \mu \mathrm{M}$. All but two of the samples have DIN $<1 \mu \mathrm{M}$. The DIN values observed in the Ivačičeva Cave ice are lower than the average DIN in ice of $15 \mu \mathrm{M}$ and $24 \mu \mathrm{M}$ observed respectively in Paradana Cave and Snežna Cave, two other ice caves in Slovenia studied (Carey et al. 2019). The similar values observed in the Triglav area glacier ice of $6.5 \mu \mathrm{M}$ 
and the cave ice of $6.3 \mu \mathrm{M}$ suggest that the DIN mass flux behaves conservatively in the glaciokarst flow systems in the Triglav area. The dissolved $\mathrm{PO}_{4}{ }^{3-}$ concentrations were at or below $0.50 \mu \mathrm{M}$ in all the samples with the majority of samples measuring $<0.1 \mu \mathrm{M}$, with very low values in the Skuta Glacier ice and in the cave ice (Table 1).

The DIN:P molar ratios varied widely, from app. 2 to 390 in the ice to a ratio of 622 in the spring water (Table 1). The glacier melt yielded DIN:P of 72 and 92.5, higher than those of aquatic vegetation (app. 16) but lower than DIN:P for trees of app. 165 (Sterner and Elser 2002). It is not clear what these large variations of dissolved N:P ratios mean or if they truly reflect any biogeochemical significance. The low $\mathrm{PO}_{4}{ }^{3-}$ concentrations reflect its particle reactivity (and removal during the filtration step), and the presence of oxidizing conditions in all of these milieux.

\subsection{Isotopic data}

As noted above, the $\delta^{18} \mathrm{O}$ and $\delta \mathrm{D}$ values fall close to the regional meteoric water line, suggesting little to no evaporation, sublimation, nor transpiration has occurred (Figure 5). The two glacier ice $\delta^{18} \mathrm{O}$ samples had values of $-8.9 \%$ and $-8.7 \%$, while the glacier melt water was lighter, at $-10.08 \%$. The Triglav Shaft ice had a greater range of $\delta^{18} \mathrm{O},-12.10 \%$ o to $-9.64 \%$ which may suggest a seasonal variation of snow and water input. This pattern may also represent even longer time variations than seasonal ones, as we do not know the true age of this material. However, the melt and spring waters are generally more enriched than the glacier ice values. Whether this enrichment is due to some evaporitic loss or melt actually being generated from ice (or more recent snow) with a heavier isotopic signature cannot be determined.

The cave ice samples show little variation in $\delta^{18} \mathrm{O}$, similar to what has been observed in the Snežna Cave ice app. $70 \mathrm{~km}$ to the east of the Triglav Glacier (Carey et al. 2019). This observation suggests that the ice from which we obtained samples may have originated from one water mass or from a constant or nearly constant isotopic source, as has been suggested previously for the Snežna Cave (Carey et al. 2019).

The unusual environmental setting of high elevation karst has allowed these ice caves to exist in a colder climate but continued warming (Hrvatin and Zorn 2017; 2018) will drive the loss of this part of the terrestrial cryosphere and perhaps the loss of the paleoclimate information contained therein. In addition, the terrestrial cryosphere will continue to transform in underground karst cryosphere, so the monitoring of the process is of essential.

\section{Conclusion}

We have sampled glacier ice, meltwater, spring water, and cave ice in the Triglav Glacier area and on the Skuta Glacier in the southeastern Alps (Slovenia) and analyzed these materials for major cations and anions, nutrients, and water stable isotopes. The samples primarily reflect the initial precipitation signal that has been greatly modified by the input of local $\mathrm{CaCO}_{3}$-rich dust with lesser amounts of marine aerosol and vegetation debris. There is surprisingly little variation between the glacier ice and meltwater in their major elemental composition. The $\mathrm{H}_{4} \mathrm{SiO}_{4}$ also varies little, indicating the lack of silicate mineral weathering in those environments. The dissolved $\mathrm{PO}_{4}{ }^{3-}$ concentrations are very low while the DIN concentrations vary by more than an order of magnitude. This produces DIN:P ratios that also vary greatly and thus limit our

Table 3: Comparison of mean chemistry from Triglav Glacier samples with Mt. Ortles snow pit chemistry (Gabrielli et al. 2010). Enrichment factors are calculated as Triglav Glacier chemistry divided by that of the Mt. Ortles snow pit.

\begin{tabular}{lcccccc}
\hline Mean values & $\mathrm{Cl}$ & $\mathrm{SO}_{4}$ & $\mathrm{Na}$ & $\mathrm{K}$ & $\mathrm{Mg}$ & $\begin{array}{c}\mathrm{Ca} \\
\mu \mathrm{M}\end{array}$ \\
& $\mu \mathrm{M}$ & $\mu \mathrm{M}$ & $\mu \mathrm{M}$ & $\mu \mathrm{M}$ & $\mu \mathrm{M}$ & $\begin{array}{c}\mathrm{M} \\
\text { Mt. Ortles snow pit at 3860 }\end{array}$ \\
Mean Triglav Glacier & 2.4 & 2.1 & 1.9 & 0.4 & 4.2 & 7.7 \\
Mean Ivačiceva Cave ice & 4.3 & 12.0 & 5.5 & 2.3 & 4.5 & 145 \\
Triglav Glacier enrichment factor & 1.6 & 7.0 & & & & \\
\hline
\end{tabular}




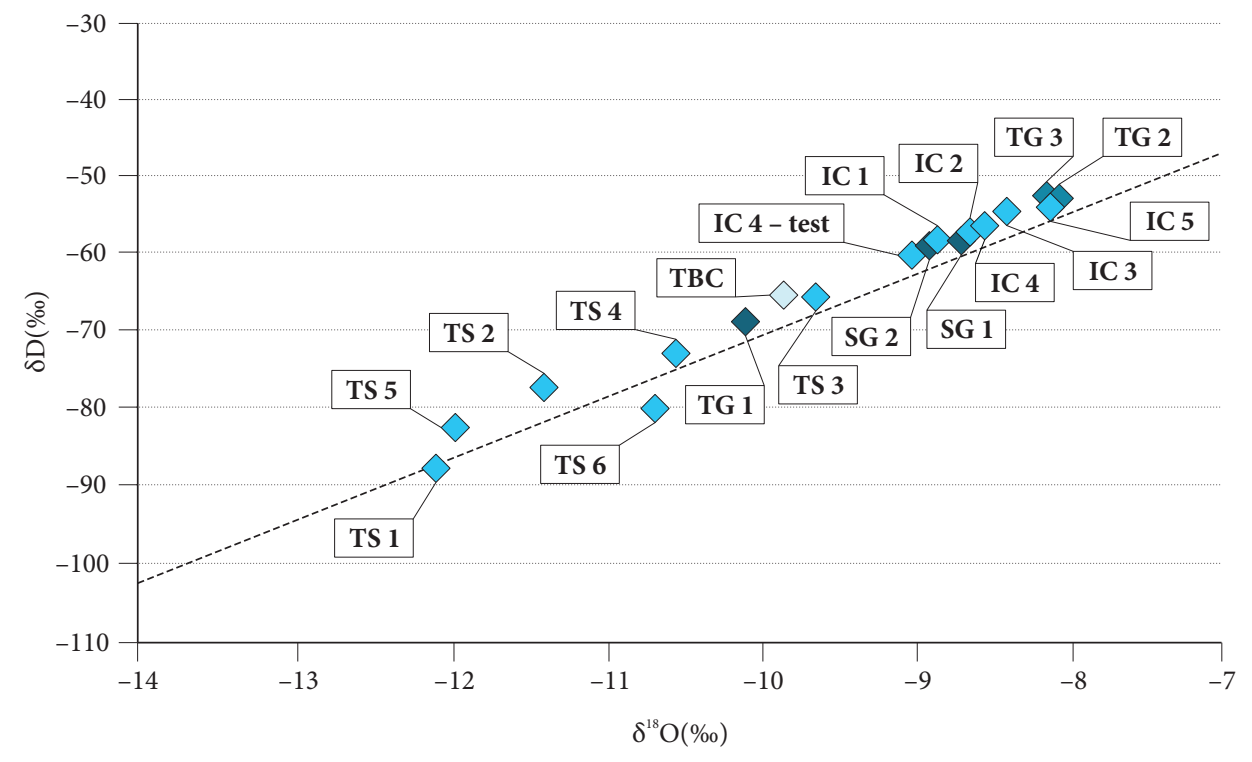

Figure 5: Triglav glacier area samples collected during 2017-2018. Also plotted is the regional meteoric water line for Slovenia of $\delta D=7.94^{*} \delta^{18} 0+9.029$ (regional line developed by Carey et al. 2019). Samples used to calculate the regional meteoric water line were collected at Global Network for Isotopes in Precipitation (GNIP) sites: Ljubljana (336 samples from 1981-2010), Portorož (84 samples from 2000-2006), and Kozina (39 samples from 2000-2003) (from data of Vreča et al. 2006; 2014). All GNIP data are available at the website of the International Atomic Energy Agency (Internet 1).

ability to evaluate the sources of and the ecological impacts of these nutrients within this environment. The $\delta^{18} \mathrm{O}$ and $\delta \mathrm{D}$ values of the sample fall very close to the regional meteoric water line indicating very little modification of the primary precipitation by other processes, such as evaporation. The rapid loss of glacier ice, as documented by the on-going work of personnel from the ZRC SAZU Anton Melik Geographic Institute (e.g., Gabrovec 2013; 2014), and also the loss of cave ice, as documented by Mihevc (2018) and others (Colucci et al. 2016), suggest strongly that in this region of the southeastern Alps the cryosphere is rapidly being lost due to climate warming and the increasing summer temperatures will undoubtedly hasten the loss.

ACKNOWLEDGEMENTS: We are very grateful for the support from The Ohio State University's Slovene Research Initiative that supported the collaboration of Anne E. Carey and W. Berry Lyons with Matija Zorn, Blaž Komac, Jure Tičar, and Matej Lipar. Partial support came from research program no. P6-0101 and infrastructure programme no. I0-0031 of the Slovenian Research Agency.

\section{References}

Carey, A. E., Zorn, M., Tičar, J., Lipar, M., Komac, B., Welch, S. A., Smith, D. F., Lyons, W. B. 2019: Glaciochemistry of Cave Ice: Paradana and Snežna Caves, Slovenia. Geosciences 9-2. DOI: https://doi.org/10.3390/ geosciences 9020094

Colucci, R. R., Fontana, D., Forte, E., Potleca, M., Guglielmin, M. 2016: Response of ice caves to weather extremes in the southeastern Alps, Europe. Geomorphology 261. DOI: https://doi.org/10.1016/ j.geomorph.2016.02.017 
Del Gobbo, C., Colucci, R. R., Forte, E., Triglav Čekada, M., Zorn, M. 2016: The Triglav Glacier (SouthEastern Alps, Slovenia): volume estimation, internal characterization and 2000-2013 temporal evolution by means of ground penetrating radar measurements. Pure and Applied Geophysics 173-8. DOI: https://doi.org/10.1007/s00024-016-1348-2

Gabrielli, P., Carturan, L., Gabrieli, J., Dinale, R., Krainer, K., Hausmann, H., Davis, M., Zagorodnov, V., Seppi, R., Barbante, C., Dalla Fontana, G., Thompson, L. G. 2010: Atmospheric warming threatens the untapped glacial archive of Ortles mountain, South Tyrol. Journal of Glaciology 56-199. DOI: https://doi.org/10.3189/002214310794457263

Gabrovec, M., Hrvatin, M., Komac, B., Ortar, J., Pavšek, M., Topole, M., Triglav Čekada, M., Zorn, M. 2014: Triglavski ledenik. Geografija Slovenije 30. Ljubljana. DOI: https://doi.org/10.3986/9789610503644

Gabrovec, M., Ortar, J., Pavšek, M., Zorn, M., Triglav Čekada, M. 2013: The Triglav Glacier between the years 1999 and 2012. Acta geographica Slovenica 53-2. DOI: https://doi.org/10.3986/AGS53202

Grunewald, K., Scheithauer, J. 2010: Europe's southernmost glaciers: response and adaptation to climate change. Journal of Glaciology 56-195. DOI: https://doi.org/10.3189/002214310791190947

Hrvatin, M., Zorn, M. 2017: Trendi pretokov rek v slovenskih Alpah med letoma 1961 in 2010. Geografski vestnik 89-2. DOI: https://doi.org/10.3986/GV89201

Hrvatin, M., Zorn, M. 2018: Recentne spremembe rečnih pretokov in pretočnih režimov v Julijskih Alpah. Triglav 240. Ljubljana. DOI: https://doi.org/10.3986/9789610500841

Internet 1: https://nucleus.iaea.org/wiser/index.aspx (9. 9. 2019).

Kumar, R. 2011: Glacieret. Encyclopedia of Snow, Ice and Glaciers. Dordrecht. DOI: https://doi.org/10.1007/ 978-90-481-2642-2_203

Kunaver, J. 1983: Geomorfološki razvoj Kaninskega pogorja. Geografski zbornik 22.

Lipar, M., Martín-Pérez, A., Tičar, J., Pavšek, M., Gabrovec, M., Hrvatin, M., Komac, B., Zorn, M., Zupan Hajna, N., Zhao, J.-X., Drysdale, R. N., Ferk, M. 2021; Subglacial carbonate deposits as a potential proxy for a glacier's former presence. The Cryosphere 15. DOI: https://doi.org/10.5194/tc-15-17-2021

Lyons, B., Foley, K., Carey, A., Diaz, M., Bowen, G., Cerling, T. 2020: The isotopic geochemistry of $\mathrm{CaCO}_{3}$ encrustations in Taylor Valley, Antarctica: Implications for their origin. Acta geographica Slovenica 60-2. DOI: https://doi.org/10.3986/AGS.7233

Lyons, W. B., Nezat, C. A., Benson, L. V., Bullen, T. D., Graham, E. Y., Kidd, J., Welch, K. A., Thomas, J. M. 2002: Strontium isotopic signatures of the streams and lakes of Taylor Valley, southern Victoria Land, Antarctica: Chemical weathering in a polar climate. Aquatic Chemistry 8. DOI: https://doi.org/10.1023/ A:1021339622515

Mihevc, A. 2018: Ice caves in Slovenia. Ice Caves. Amsterdam. DOI: https://doi.org/10.1016/B978-0-12811739-2.00030-9

Mikša, P., Zorn, M. 2016: The beginnings of the research of Slovenian Alps. Geografski vestnik 88-2. DOI: https://doi.org/10.3986/GV88206

Miler, M. 2014: SEM/EDS characterisation of dusty deposits in precipitation and assessment of their origin. Geologija 57-1. DOI: https://doi.org/10.5474/geologija.2014.001

Miler, M., Gosar, M. 2015: Chemical and morphological characteristics of solid metal-bearing phases deposited in snow and stream sediment as indicators of their origin. Environmental Science and Pollution Research International 22. DOI: https://doi.org/10.1007/s11356-014-3589-x

Mioč, P. 1983: Osnovna geološka karta SFRJ $1: 100.000$, tolmač lista Ravne na Koroškem. Zvezni geološki zavod. Beograd.

Nadbath, M. 2014: Meteorološka postaja Kredarica. Naše okolje 21-8.

Pavšek, M. 2004: Ledenik pod Skuto: ledeniški dragulj na senčni strani Kamniško-Savinjskih Alp. Geografski obzornik 51-3.

Pavšek, M. 2007: Ledenik pod Skuto kot pokazatelj podnebnih sprememb v slovenskem delu Alp. Dela 28. DOI: https://doi.org/10.4312/dela.28.207-219

Reynard, E., Coratza, P. 2016: The importance of mountain geomorphosites for environmental education: examples from the Italian Dolomites and the Swiss Alps. Acta geographica Slovenica 56-2. DOI: https://doi.org/10.3986/AGS.1684

Sterner, R. W, Elser, J. J. 2002: Ecological Stoichiometry: Biology of Elements from Molecules to the Biosphere. Princeton. 
Šmuc, A., Rožič, G. 2009: Tectonic geomorphology of the Triglav Lakes Valley (easternmost Southern Alps, NW Slovenia). Geomorphology 103-4. DOI: https://doi.org/10.1016/j.geomorph.2008.08.005

Tičar, J., Lipar, M., Zorn, M., Kozamernik, E. 2018: Triglavsko podzemlje. Triglav 240. Ljubljana. DOI: https://doi.org/10.3986/9789610500841

Triglav Čekada, M., Barbo, P., Pavšek, M., Zorn, M. 2020: Changes in the Skuta Glacier (southeastern Alps) assessed using non-metric images. Acta geographica Slovenica 60-2. DOI: https://doi.org/10.3986/ AGS.7674

Triglav Čekada, M., Zorn, M. 2020: Thickness and geodetic mass balance changes for the Triglav Glacier (southeastern Alps) from 1952 to 2016. Acta geographica Slovenica 60-2. DOI: https://doi.org/10.3986/ AGS.7673

Triglav Čekada, M., Zorn, M., Colucci R. R. 2014: Changes in the area of the Canin (Italy) and Triglav glaciers (Slovenia) since 1893 based on archive images and aerial laser scanning. Geodetski vestnik 58-2. DOI: https://doi.org/10.15292/geodetski-vestnik.2014.02.274-313

Vreča, P., Krajcar Bronić, I., Horvatinčić, N., Barešić, J. 2006. Isotopic characteristics of precipitation in Slovenia and Croatia: Comparison of continental and maritime stations. Journal of Hydrology 330, 3-4. DOI: https://doi.org/10.1016/j.jhydrol.2006.04.005

Vreča, P., Krajcar Bronić, I., Leis, A., Demšar, M. 2014: Isotopic composition of precipitation at the GNIP station Ljubljana (Reaktor), Slovenia - period 2007-2010. Geologija 57-2. DOI: https://doi.org/10.5474/ geologija.2014.019

Welch, K. A., Lyons, W. B., Whisner, C., Gardner, C. B., Gooseff, M. N., McKnight, D. M., Priscu, J. C. 2010: Spatial variations in the geochemistry of glacial meltwater streams in the Taylor Valley, Antarctica. Antarctic Science 22-6. DOI: https://doi.org/10.1017/S0954102010000702

Yao, T., Liu, Y., Zhao, H., Yu, W. 2011: Geochemistry of snow and ice. Encyclopedia of Snow, Ice and Glaciers. Dordrecht. DOI: https://doi.org/10.1007/978-90-481-2642-2_176

Zorn, M. 2009: Erosion processes in Slovene Istria - part 1: Soil erosion. Acta geographica Slovenica 49-1. DOI: https://doi.org/10.3986/AGS49102

Zorn, M., Hrvatin, M., Perko, D. 2020: Hydrological connectivity: an introduction to the concept. Geografski vestnik 92-1. DOI: https://doi.org/10.3986/GV92102

Zupančič, N., Horvat, A., Skobe, S. 2015: Environmental impact of dusting from the Koper port bulk cargo terminal on the agricultural soils. Acta geographica Slovenica 55-1. DOI: https://doi.org/10.3986/AGS.826

Žebre, M., Stepišnik, U. 2015: Glaciokarst landforms and processes of the southern Dinaric Alps. Earth Surface Processes and Landforms 40-11. DOI: https://doi.org/10.1002/ESP.3731 